\title{
Undergraduate Hispanic Student Response To Cooperative Learning
}

Bobbette M. Morgan, University of Texas at Brownsville, USA

Graciela P. Rosenberg, University of Texas at Brownsville, USA

Lori Wells, University of Texas at Brownsville, USA

\begin{abstract}
Three classes of undergraduate Hispanic students assigned to an ESL professor and a teaching assistant were selected to experience cooperative learning over a full semester. Pre-semester surveys were completed by 80 undergraduate students. Post-semester surveys were completed by 66 undergraduate students. Strategies used in the classes included Think-Pair-Share, Ticket Out the Door, Jigsaw and being a member of a base group. This study is based upon theories of social interdependence, cognitive development, and behavioral learning. The surveys were completed by the university students to compare and contrast knowledge about their experiences in: 1) individual learning, and 2) learning with a partner.
\end{abstract}

Keywords: cooperative learning; undergraduate education; minority population

\section{INTRODUCTION}

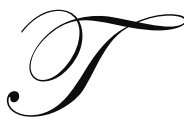

he purpose of the study is to share results regarding undergraduate Hispanic students and their experiences with individual learning and cooperative learning. Survey results are shared. The convenient sample consisted of undergraduates enrolled in three classes, one an ESL education course and two sections of an introductory education course. Eighty students completed both pre- and post- surveys. Participants were primarily first and second-generation immigrants from Mexico, South America, and Cuba and often the first in their family to attend an institution of higher learning. This institution, with a $94 \%$ Hispanic population, is located on the south Texas-Mexico border.

\section{THEORETICAL PERSPECTIVES}

The theoretical framework for this paper centers on cooperative learning. Cooperative learning has its roots in the theories of social interdependence, cognitive development, and behavioral learning. Some research provides exceptionally strong evidence that cooperative learning results in greater effort to achieve, more positive relationships, and greater psychological health than competitive or individualistic learning efforts (Johnson, Johnson, \& Holubec, 1994).

Social interdependence theory views cooperation as resulting from positive links of individuals to accomplish a common goal. The Gestalt psychologist Kurt Kaffka proposed in the early 1900's that although groups are dynamic wholes the interdependence among members is variable. Kurt Lewin (1948) stated that interdependence from common goals provides the essential essence of a group. This interdependence creates groups that are dynamic wholes.

Within cognitive development theory, cooperation must precede cognitive growth. Cognitive growth springs from the alignment of various perspectives as individuals work to attain common goals. Both Piaget and Vygotsky saw cooperative learning with more able peers and instructors as resulting in cognitive development and intellectual growth (Johnson, Johnson, \& Smith, 1998). 
The assumption of behavioral learning theory is that students will work hard on tasks that provide a reward and that students will fail to work on tasks that provide no reward or punishment. Cooperative learning is one strategy that rewards individuals for participation in the group's effort.

The Johnson and Johnson model of Cooperative Learning includes the following five elements:

1. Positive Interdependence — creating the feeling that the group "sinks or swims together."

2. Face-to-Face Interaction - each team needs to sit in close proximity, eye-to-eye and knee-to-knee.

3. Individual Accountability - each person must know the material.

4. Social Skills - each student must work at implementing the selected social skill and the instructor must monitor for its use.

5. Processing - the opportunity to reflect on how well they functioned as a team and what they can do next time to be even better.

From their review of the research on collaborative learning in higher education, Elizabeth Barkley, Patricia Cross, and Claire Major (2005) have found abundant evidence that collaborative learning is an effective and motivating format for non-traditional underrepresented racial and ethnic groups, working-adult students, commuters, and re-entry students. Collaborative learning reframes the student role by requiring students to shift from a passive, privatized, and competitive learning to active, public, and cooperative ways of working (National Learning Communities Project, 2003).

The widespread use of cooperative learning is due to multiple factors. According to Johnson and Johnson (2002) three of the most important factors are that cooperative learning is clearly based on theory, validated by research, and operationalized into clear procedures educators can use.

There are over 900 research studies validating the effectiveness of cooperative learning over competitive and individualistic efforts. This body of research has considerable generalizability for more than 110 years the research has been conducted by a wide range of researchers with markedly different orientations working in various settings and countries. The research participants have varied widely as to cultural background, economic class, age, and gender. Further more, a wide variety of research tasks and measures of the dependent variables have been used (Johnson and Johnson, 2002).

\section{METHODS AND DATA SOURCES}

Data collection for the mixed methods study occurred over one academic semester with students attending a community university. Eighty undergraduate Hispanic students completed pre- surveys and sixty-six completed post-surveys. The surveys included two types of questions and were adapted with permission from a Johnson and Johnson survey. The students were asked to rate their knowledge of cooperative learning on a scale of one to five with one being lowest and five being highest. Students were asked to indicate their experiences with cooperative learning in both the pre- and post survey. The consistency of questions and possible response options on the pre- and post-surveys allowed researchers to make comparisons about students' knowledge of cooperative learning and perceptions of expertise before and after the course (Fraenkel \& Wallen, 1996).

In addition the post-survey students were asked summarize, with their assigned cooperative partner, what they had learned. The "Ticket Out the Door" strategy provided students with practice of reassembling their memories and the opportunity to complete the "articulatory loop" by discussing the material covered (Zadina, 2008). The cooperative assignment of one summary for each pair of students provided them a partner to clarify information and complete their "Ticket Out the Door". The professor collected the "Tickets" from each team as they left the room. Their summaries were reviewed for content and feedback about the class.

The use of standardized open-ended questions allowed the researchers to focus the students' attention on certain topics of interest without limiting the possible responses. It also allowed the researchers to gather data from the perspective of the undergraduate ... students (Patton, 1990). The reflections and responses summarizing what the cooperative pairs of students had shared were analyzed using an inductive approach. The researchers searched for 
patterns in the data and then categorized the data according to the patterns that emerged (Krathwohl, 1993). This was done by searching for patterns separately. The researchers then shared the categories that they had found in the data and further refined their categories, thus providing a peer check of the analysis (Carspecken, 1996). Multiple data sources and peer checks were used to triangulate the emerging findings and to contribute to the credibility of the study (Patton, 1990).

\section{RESULTS}

The pre- and post-semester survey results, that included Likert-type responses on a scale of $5=$ high and 1 $=$ low, were summarized for 15 questions.

Table 1: Student Pre- and Post-Survey Results

\begin{tabular}{|c|c|c|c|c|c|c|c|}
\hline Item \# & Five point Likert scale used, $5=$ Highest and $1=$ Lowest. & $\begin{array}{l}\text { Pre- } \\
\text { Post- }\end{array}$ & $\begin{array}{c}\% \\
1.00\end{array}$ & $\begin{array}{c}\% \\
2.00\end{array}$ & $\begin{array}{c}\% \\
3.00\end{array}$ & $\begin{array}{c}\% \\
4.00\end{array}$ & $\begin{array}{c}\% \\
5.00\end{array}$ \\
\hline \multirow[t]{2}{*}{1.} & \multirow{2}{*}{$\begin{array}{l}\text { I believe that cooperative learning is an effective instructional } \\
\text { technique in most content areas. }\end{array}$} & Pre- & 0 & 0 & 22.5 & 37.5 & 40.0 \\
\hline & & Post- & 0 & 0 & 3.0 & 24.2 & 72.7 \\
\hline \multirow[t]{2}{*}{2.} & \multirow{2}{*}{$\begin{array}{l}\text { I believe that cooperative learning increases student participation } \\
\text { in learning activities. }\end{array}$} & Pre- & 0 & 0 & 18.8 & 38.8 & 42.5 \\
\hline & & Post- & 0 & 0 & 0 & 24.2 & 75.7 \\
\hline \multirow[t]{2}{*}{3.} & \multirow{2}{*}{$\begin{array}{l}\text { I believe that cooperative learning improves student } \\
\text { communication and decision-making skills. }\end{array}$} & Pre- & 0 & 0 & 17.5 & 40.0 & 42.5 \\
\hline & & Post- & 0 & 0 & 4.6 & 16.9 & 78.5 \\
\hline \multirow[t]{2}{*}{4.} & \multirow{2}{*}{$\begin{array}{l}\text { I believe that cooperative learning encourages and improves the } \\
\text { performance of high ability students. }\end{array}$} & Pre- & 0 & 0 & 31.3 & 30.0 & 38.8 \\
\hline & & Post- & 0 & 1.5 & 7.6 & 27.3 & 63.6 \\
\hline \multirow[t]{2}{*}{5.} & \multirow{2}{*}{$\begin{array}{l}\text { I believe that cooperative learning encourages and improves the } \\
\text { performance of average ability students. }\end{array}$} & Pre- & 0 & 0 & 27.5 & 36.3 & 36.3 \\
\hline & & Post- & 0 & 1.5 & 3.0 & 27.3 & 68.2 \\
\hline \multirow[t]{2}{*}{6.} & \multirow{2}{*}{$\begin{array}{l}\text { I believe that cooperative learning encourages and improves the } \\
\text { performance of low ability students. }\end{array}$} & Pre- & 0 & 0 & 32.5 & 26.3 & 41.3 \\
\hline & & Post- & 0 & 3.0 & 3.0 & 24.2 & 69.7 \\
\hline \multirow[t]{2}{*}{7.} & \multirow{2}{*}{$\begin{array}{l}\text { I believe that using cooperative learning is an efficient teaching } \\
\text { technique. }\end{array}$} & Pre- & 0 & 0 & 27.5 & 33.8 & 38.8 \\
\hline & & Post- & 0 & 0 & 3.0 & 31.8 & 65.2 \\
\hline \multirow[t]{2}{*}{8.} & \multirow{2}{*}{$\begin{array}{l}\text { I plan to increase my use of cooperative learning by organizing a } \\
\text { cooperative study group. }\end{array}$} & Pre- & 2.5 & 3.8 & 40.5 & 26.6 & 26.6 \\
\hline & & Post- & 0 & 0 & 13.6 & 34.8 & 51.5 \\
\hline \multirow[t]{2}{*}{9.} & \multirow{2}{*}{$\begin{array}{l}\text { Rewarding individual performance based on group success is an } \\
\text { equitable method of grading. }\end{array}$} & Pre- & 1.3 & 7.7 & 44.9 & 29.5 & 16.7 \\
\hline & & Post- & 3.0 & 4.5 & 12.1 & 51.5 & 28.8 \\
\hline \multirow[t]{2}{*}{10.} & \multirow{2}{*}{$\begin{array}{l}\text { I plan to make use of future opportunities for additional training in } \\
\text { cooperative learning. }\end{array}$} & Pre- & 0 & 1.3 & 32.5 & 28.8 & 37.5 \\
\hline & & Post- & 0 & 1.5 & 3.0 & 40.9 & 54.5 \\
\hline \multirow[t]{2}{*}{11.} & \multirow{2}{*}{$\begin{array}{l}\text { How would you rate your theoretical knowledge regarding } \\
\text { cooperative learning? }\end{array}$} & Pre- & 2.5 & 25.3 & 39.2 & 24.1 & 8.9 \\
\hline & & Post- & 0 & 0 & 12.3 & 53.8 & 33.8 \\
\hline \multirow[t]{2}{*}{12.} & \multirow{2}{*}{$\begin{array}{l}\text { How would you rate your knowledge regarding the effective } \\
\text { implementation of cooperative learning as a model of teaching? }\end{array}$} & Pre- & 3.8 & 19.0 & 43.0 & 27.8 & 6.3 \\
\hline & & Post- & 0 & 1.5 & 12.1 & 54.5 & 31.8 \\
\hline \multirow[t]{2}{*}{13.} & \multirow{2}{*}{$\begin{array}{l}\text { As an "expert" for part of the material we need to learn, makes me } \\
\text { prepare more carefully. }\end{array}$} & Pre- & 0 & 0 & 42.1 & 40.8 & 17.1 \\
\hline & & Post- & 0 & 0 & 6.1 & 53.0 & 40.9 \\
\hline \multirow[t]{2}{*}{14.} & \multirow{2}{*}{$\begin{array}{l}\text { In a jigsaw activity I listen carefully to my peers to learn the } \\
\text { material they are "experts" in. }\end{array}$} & Pre- & 0 & 0 & 41.3 & 33.3 & 25.3 \\
\hline & & Post- & 0 & 1.5 & 6.2 & 43.1 & 49.2 \\
\hline \multirow[t]{2}{*}{15.} & \multirow{2}{*}{$\begin{array}{l}\text { In a jigsaw activity I gain an understanding of the material } \\
\text { through discussion with my peers. }\end{array}$} & Pre- & 0 & 0 & 41.3 & 32.0 & 26.7 \\
\hline & & Post- & 0 & 1.6 & 9.4 & 45.3 & 43.8 \\
\hline
\end{tabular}

\section{RESULTS OF COOPERATIVE ACTIVITIES}

Students were asked to provide summaries of what they had learned during the semester. The summaries were prepared by the students with a partner that they worked with at least half of the semester. Three formats were used:

1. Ticket to Out the Door: Each group of two students jointly summarized what they had learned that day. The pair could not leave until they wrote their ticket providing feedback on what they learned. 
2. Think-Pair-Share: The pairs of students were asked to think about what was presented that day, discuss it with their partner, and share it in a summary statement.

3. Group Review: During the semester students were asked to summarize what they had learned. Students were, with their partners, asked to review their notes and write a response in class. Each pair of students had a different question and reported out orally as well as turning in their written response to the professor. This provided a review of major topics addressed.

Students responded individually to the following open ended questions as part of the post-survey included, "Describe how you felt participating in cooperative learning groups." and "Describe your experiences in cooperative learning groups."

Students wrote about enjoying working as part of a cooperative group and feeling that they learned more through this experience.

- $\quad$ "I like working as a cooperative group member. I get to learn and express my ideas to others. I get to help and ask questions about problems that I have."

- $\quad$ "I enjoyed participating in cooperative learning groups. It made me feel more comfortable when having to speak in class. I met new people who are interested in the same career I am, and that will help me out in the future."

- $\quad$ "It was great listening to others point of views. We are here to learn and everyone's opinion mattered. When you had something to say, usually someone else had some thoughts or added to your opinion."

- $\quad$ "I liked the experience. I felt better to know that together we would learn more. Some of us would remember more from one subject than the other and we would be able to teach each other."

- $\quad$ "I felt intelligent and that my thoughts and ideas were being evaluated and used much of the time. I really enjoyed working in groups because you listened to different opinions and learned even more."

Students indicated that they were uncomfortable at first, but that they enjoyed the experience in the end.

- $\quad$ "At first I was skeptical, but with time I felt comfortable and glad that the weight of an assignment was not just put on myself."

- $\quad$ "At the beginning I did not like it because I really did not know how I was going to work with other people. I was also a shy person, but I ended up liking it because I learned a lot from the other students, because everybody has different skills, opinions, and ideas. In fact, I really enjoyed working in a cooperative learning group."

- $\quad$ "I was a bit scared at first that I would be a burden to my group members, but I discovered I can be a very important asset to my team. It was a wonderful experience I enjoyed a lot."

- $\quad$ "At first, I was not excited about working in groups. My experience in the past has not been very good. At the end I was glad to have had a great group."

- $\quad$ "I felt uncomfortable at first, but as time passed, it was great. Working in groups helped me to be more open in class."

- $\quad$ "I was hesitant about participating for I did not know what to expect. Now I know, after participating in cooperative learning, that it is magnificent. Getting to share ideas, materials, and feelings is wonderful."

- $\quad$ "My experiences with working with groups in the past were not very positive. That changed this semester for me. I learned that it's ok to depend on others, although it wasn't successful $100 \%$ of the time. Still, cooperative learning is something I'm definitely going to use in my classroom."

- $\quad$ "At first I was a little resistant because I do not consider myself very smart, and I was afraid to be faced with a smart person, and not being able to carry my own weight. But cooperative learning actually did the opposite. It gave me more confidence, and made me more responsible to be prepared for every class.

Students spoke about feeling more confident when working in a group because they had others to rely on.

- $\quad$ I felt I had a safety net in case I missed something." 
- $\quad$ "Working and participating in cooperative groups, I learned a great deal from people. I felt more confident in presenting projects and taking tests."

- $\quad$ "After 9 years away from school, coming back was difficult...but through cooperative learning group I got back on track."

- $\quad$ "I really enjoyed it. It makes you aware of different ideas that you might not have thought about on our own. It makes getting to know your classmates an easy experience."

- $\quad$ "I find it easier because I know that the work is divided and not all of the attention will be on me. It helps me learn and gain confidence in front of people."

- $\quad$ "Cooperative group work is something I feel helped me gain more confidence in speaking with other people. You also get to know people better and you learn to trust them as well."

- $\quad$ "It was very fun and I really learned a lot from my group members."

Others wrote about the opportunity to get to know their classmates better.

- "Working together, helps me to know new people, and feels like I'm putting my part into the project."

- $\quad$ "I've had a great learning experience, especially with the group I started with. Not only did we learn from each other, but we have become very good friends. It's a great learning experience for those who are truly very shy. It certainly breaks the ice."

\section{DISCUSSION}

The results of this study add to the body of knowledge about use of cooperative learning strategies with Hispanic undergraduate students. Pre- and post surveys, summaries about their learning with partners and selfreporting about their experiences in a classroom where cooperative learning strategies were utilized provides information about undergraduate Hispanic students in undergraduate courses. The undergraduate Hispanic students were involved in the project over the period of a full semester.

No hypotheses are stated, but the clearly implied directional hypothesis is: undergraduate Hispanic students experiencing cooperative learning over one full semester show significant changes in pre- and post survey results including that they enjoy the interaction with peers, that cooperative learning encourages and improves the performance of all students, that when they work in small groups they make sure that everyone learns the material, everyone's ideas are needed to be successful in the small groups, and working in a jigsaw helps them learn the material.

The qualitative data that was gathered indicates that the majority of students enjoyed the experience of participating in cooperative learning. Several students reported that they had experienced some small group learning activities in the past that did not include all of the elements of cooperative learning with less success, but that the elements of cooperative learning improved their experience with small group work. Another theme that was apparent in the qualitative data was that students felt they had a safety net. They were more confident when performing difficult tasks such as giving a presentation or taking a test.

\section{AUTHOR INFORMATION}

Bobbette M. Morgan, Ed. D., Professor, is a member of the College of Education in the Teaching, Learning and Innovation Department at The University of Texas at Brownsville and Texas Southmost College. Her interests include cooperative learning, adult learning strategies, brain-compatible learning and research-based models of teaching. She currently serves as Director of the Office of Graduate Programs in the College of Education.

Graciela P. Rosenberg, Ed. D., Professor, is a member of the College of Education in the Language, Literacy, and Intercultural Studies Department at The University of Texas at Brownsville and Texas Southmost College. Her interests include ESL, Comparative Education, and Literature. 
Lori Wells serves as a Teaching Assistant in the College of Education in the Teaching, Learning, and Innovation Department and in the Language, Literacy, and Intercultural Studies Department. She is a doctoral student in the Doctor of Education in Curriculum and Instruction Program with a specialization in Bilingual Studies.

\section{REFERENCES}

1. Barkley, E. F., Cross, K. P. \& Major, C. H. (2005). Collaborative learning techniques: A handbook for college faculty. San Francisco, CA: Jossey-Bass.

2. Carspecken, P. F. (1996). Critical ethnography in educational research: A theoretical and practical guide. New York: Routledge.

3. Fraenkel, J. R. \& Wallen, N. E. (1996). How to design and evaluate research in education ( $3^{\text {rd }}$ ed.). New York: McGraw-Hill.

4. Johnson, R. T. \& Johnson, D. W. (1994). An overview of cooperative learning. [on-line]. Available: http://www.co-operation.org [date accessed: 6-30-04]

5. Johnson, D., Johnson, R., \& Holubec, E. (1994). Cooperative learning in the classroom. Alexandria, VA: Association for Supervision and Curriculum Development.

6. Johnson, D., Johnson R., \& Smith, K. (1998). Cooperative learning returns to college. Change. 30 (4): 2635 .

7. Krathwohl, D. R. (1993). Methods of educational and social science research: An integrated approach. New York: Longman.

8. $\quad$ Lewin, K. (1948). Resolving social conflicts. New York: Harper.

9. National Learning Communities Project (2003). The pedagogy of possibilities: Developmental education, college-level studies, and learning communities. Monograph Series: The Washington Center for Improving the Quality of Undergraduate Education at Evergreen State College in Cooperation with the American Association for Higher Education.

10. Patton, M. (1990). Qualitative evaluation and research methods $\left(2^{\text {nd }}\right.$ ed.). Newbury Park, CA: Sage Publications, Inc.

11. Zadina, J. (2008). Six weeks to a brain compatible classroom. Printed in the United States of America. jzadina@uno.edu. 